\title{
Serratia Marcescens outbreak on a general pediatric ward in Benin
}

\author{
TA Ahoyo ${ }^{1 *}$, MF Adeoti ${ }^{2}$, AG Attolou ${ }^{3}$, M Boco $^{4}$, LS Baba Moussa ${ }^{5}$ \\ From International Conference on Prevention \& Infection Control (ICPIC 2011) \\ Geneva, Switzerland. 29 June - 2 July 2011
}

\section{Introduction}

The consequences of infections with Serratia marcescens can be severe, so strategies for prevention are important.

\section{Objective}

Our study aimed to examine the resistance in this bacterium and the main factors increasing the risk of cross contamination.

\section{Methods}

6-months surveillance was conducted in the pediatric unit in Benin, from June $15^{\text {th }}$ to December $15^{\text {th }}, 2009$. We examined various specimenobtained from hospitalized children and 940 samples taken from hands of medical personnel, and various hospital surfaces for Serratia marcescens presence. Susceptibilities against antimicrobial agents were tested by the disk diffusion method according to NCCLS guidelines. Aggressive infection control measures were instituted.

\section{Results}

324/790 (41\%) patients were studied; 123 (39\%) were infected bySerratia marcescens, including septicaemia 65 (52,8\%). 121 children were colonized 1 month later after admission. From hospital environment, 108/940 $(11,50 \%)$ isolates were obtained. Antimicrobial susceptibility testing revealed $56 \%$ strains displaying multiresistance. Comparison of resistance patterns in isolates blood cultures with those from hands of personnel showed similitude in $92 \%$ of cases. Infected patients were cohorted and placed on contact precautions. Investigation by the infection control team revealed that the distributors of antiseptic were the main path of Serratia marcescens dissemination.

${ }^{1} \mathrm{GBH}$ Epac, University of Abomey Calavi Benin Ouest Africa, Cotonou, Benin Full list of author information is available at the end of the article

\section{Conclusion}

New infection control policies and engineering plans were initiated on the basis of our results. Antimicrobial resistance is particularly harmful to infectious disease management in low-income countries since expensive second-line drugs are not readily available.

\section{Disclosure of interest}

None declared.

\section{Note}

Also presented as P349.

\section{Author details}

${ }^{1} \mathrm{GBH}$ Epac, University of Abomey Calavi Benin Ouest Africa, Cotonou, Benin. ${ }^{2}$ BIOCHIMY, RIPAQS International, Abidjan, Cote d'Ivoire. ${ }^{3}$ Quality Assurance, Hospital, Abomey, Benin. ${ }^{4}$ Microbiology, CHDZ/C Hospital, Abomey, Benin. ${ }^{5}$ FAST, University of Abomey Calavi Benin Ouest Africa, Cotonou, Benin.

Published: 29 June 2011

doi:10.1186/1753-6561-5-S6-P299

Cite this article as: Ahoyo et al:: Serratia Marcescens outbreak on a general pediatric ward in Benin. BMC Proceedings 2011 5(Suppl 6):P299.

Submit your next manuscript to BioMed Central and take full advantage of:

- Convenient online submission

- Thorough peer review

- No space constraints or color figure charges

- Immediate publication on acceptance

- Inclusion in PubMed, CAS, Scopus and Google Scholar

- Research which is freely available for redistribution 